\title{
Growth and Acclimation of Impatiens, Salvia, Petunia, and Tomato Seedlings to Blue and Red Light
}

\author{
Heidi M. Wollaeger ${ }^{1,2}$ and Erik S. Runkle ${ }^{3,4}$ \\ Department of Horticulture, Michigan State University, 1066 Bogue Street, \\ East Lansing, MI 48824
}

Additional index words. controlled environments, extension growth, LEDs, light quality

\begin{abstract}
Plant growth is plastic and adaptive to the light environment; characteristics such as extension growth, architecture, and leaf morphology change, depending on the light spectrum. Although blue $(B ; 400-500 \mathrm{~nm})$ and red $(R ; 600-700 \mathrm{~nm})$ light are generally considered the most efficient wavelengths for eliciting photosynthesis, both are often required for relatively normal growth. Our objective was to quantify how the B:R influenced plant seedling growth and morphology and understand how plants acclimated to these light environments. We grew seedlings of three ornamental annuals and tomato under six sole-source light-emitting diode (LED) lighting treatments or one cool-white fluorescent treatment that each delivered a photosynthetic photon flux (PPF) of 160 $\mu \mathrm{mol} \cdot \mathrm{m}^{-2} \cdot \mathrm{s}^{-1}$ for $18 \mathrm{~h} \cdot \mathrm{d}^{-1}$. The following treatments were provided with $B$ (peak $=446$ $\mathrm{nm})$ and $R$ (peaks $=634$ and $664 \mathrm{~nm})$ LEDs: $B_{160}\left(160 \mu \mathrm{mol} \cdot \mathrm{m}^{-2} \cdot \mathrm{s}^{-1}\right.$ of $B$ light only), $\mathbf{B}_{80}+\mathbf{R}_{80}, \mathbf{B}_{40}+\mathbf{R}_{120}, \mathbf{B}_{20}+\mathbf{R}_{140}, \mathbf{B}_{10}+\mathbf{R}_{150}$, and $\mathbf{R}_{160}$. Seedlings of impatiens (Impatiens walleriana), salvia (Salvia splendens), petunia (Petunia $\times$ hybrida), and tomato (Solanum lycopersicum) were grown for 31 to 37 days at a constant $20{ }^{\circ} \mathrm{C}$. Plants with as little as $10 \mu \mathrm{mol} \cdot \mathrm{m}^{-2} \cdot \mathrm{s}^{-1}$ of B light were $23 \%$ to $50 \%$ shorter and had $17 \%$ to $50 \%$ smaller leaves than plants under only $R$ light. Impatiens and salvia had $53 \%$ to $98 \%$ greater fresh shoot weight under treatments without $B$ light than with $\geq 80 \mu \mathrm{mol} \cdot \mathrm{m}^{-2} \cdot \mathrm{s}^{-1}$. Plants grown under fluorescent lamps had the greatest chlorophyll content but also had among the thinnest leaves of treatments. Blue-rich light increased flowering in impatiens and reduced incidence of intumescences on tomato. We conclude that, in sole-source lighting of propagules, $B$ light inhibits leaf and stem expansion, which subsequently limits photon capture and constrains biomass accumulation. As little as $10 \mu \mathrm{mol} \cdot \mathrm{m}^{-2} \cdot \mathrm{s}^{-1}$ of $\mathrm{B}$ light in an R-dominant background can elicit desirable growth responses for the production of young plants and for other situations in which compact growth is desired.
\end{abstract}

Blue (B; 400-500 nm) and red (R; 600$700 \mathrm{~nm}$ ) light are generally considered the most efficient wavelengths for eliciting photosynthesis in plants (McCree, 1972; Sager et al., 1988). Therefore, $\mathrm{B}$ and R LEDs with peak light emission that coincides with peaks of the relative quantum efficiency curve (McCree, 1972) make a logical choice for sole-source commercial plant production (Mitchell et al., 2012). Previous results with tomato (Solanum lycopersicum), salvia (Salvia

Received for publication 18 Nov. 2014. Accepted for publication $10 \mathrm{Feb} .2015$.

We gratefully acknowledge support from Osram Opto Semiconductors, the USDA-ARS Floriculture and Nursery Research Initiative, and Michigan State University's AgBioResearch. We thank Bert Cregg for statistical advice, C. Raker \& Sons for donation of plant material, and Mike Olrich for technical assistance. This work was supported by the USDA National Institute of Food and Agriculture, Hatch project 192266.

${ }^{1}$ Former graduate research assistant and currently commercial horticulture educator.

${ }^{2}$ Present address: Michigan State University Extension, 3299 Gull Road, P.O. Box 42, Nazareth, MI 49074.

${ }^{3}$ Professor and floriculture extension specialist.

${ }^{4}$ To whom reprint requests should be addressed; e-mail runkleer@msu.edu. to suppress extension growth (Hendriks and Ueber, 1995). Extension growth can also be inhibited by modifying the light spectrum, especially by B light and the R:far-red (FR, 700-800 nm) light ratio (Liu et al., 2011a; Smith, 2000). Blue-light-stimulated cryptochrome receptors suppress gibberellic acid biosynthesis, which in turn inhibits cell elongation and stem extension of plants (Ahmad et al., 2002; Cashmore et al., 1999; Liu et al., 2011a; Sellaro et al., 2010). For example, sweetpotato (Ipomoea batatas) stems were $17 \%$ shorter when the $\mathrm{B}: \mathrm{R}$ was $1: 10$ compared with that of plants grown under a $B: R$ of $1: 4$ at a $P P F$ of $35 \mu \mathrm{mol} \cdot \mathrm{m}^{-2} \cdot \mathrm{s}^{-1}$ (Yang et al., 2011). In a separate study, cherry tomato plants grown under $\mathrm{B}$ or $\mathrm{R}+\mathrm{B}$ LEDs were $33 \%$ or $49 \%$ shorter than those grown under only $\mathrm{R}$ LEDs at a $P P F$ of $320 \mu \mathrm{mol} \cdot \mathrm{m}^{-2} \cdot \mathrm{s}^{-1}$ (Liu et al., 2011b). Phytochromes, with absorption peaks at 660 and $735 \mathrm{~nm}$, are a family of photoreceptors that mediate stem elongation, as well as leaf expansion, chloroplast development, and flowering (Folta and Childers, 2008; Horwitz et al., 1988; Parks et al., 2001; Valverde et al., 2004).

In addition to extension growth, plants acclimate to a high B:R by increasing chlorophyll concentration (Lichtenthaler et al., 1981). Blue light stimulates cryptochrome (CRY1), which upregulates the transcription of genes for chlorophyll synthesis (Li et al., 2009). High chlorophyll content in plants, which causes a dark green coloration of leaves, is also desirable in commercial production of young plants such as microgreens, herbs, and ornamental propagules. Growing plants under sole-source solid-state lighting that includes $\mathrm{B}$ light in an R-dominant background can yield this characteristic (Goins et al., 1997; Li et al., 2011; OhashiKaneko et al., 2006; Saebo et al., 1995; Tennessen et al., 1994). For example, lettuce grown under $\mathrm{B}$ or $\mathrm{B}+\mathrm{R}(1: 1)$ LEDs had $\approx 11 \%$ greater chlorophyll per unit of dry mass than plants grown under R LEDs at the same intensity (Johkan et al., 2010). In a separate study, cucumber (Cucumis sativus) had increasing chlorophyll content per unit leaf area with increasing ratios of $\mathrm{B}: \mathrm{R}$ light at the same intensity (Hogewoning et al., 2010).

Plants also acclimate to a low R:FR or B-deficient environment by increasing leaf thickness (Fan et al., 2013; Fukuda et al., 2008; Schuerger et al., 1997). Thicker leaves have not been directly attributed to cryptochrome or phototropin photoreceptors (OhashiKaneko et al., 2006). However, the CRYI cryptochrome receptor downregulates gibberellic acid biosynthesis and therefore suppresses leaf expansion, which in turn results in thicker leaves (Ahmad et al., 2002; Liu et al., 2011a; Sellaro et al., 2010). Therefore, plants grown under solely $\mathrm{R}$ light typically have larger, thinner leaves than those of plants grown under light that includes B. For example, pepper plants (Capsicum annuum) grown at a $P P F$ of $330 \mu \mathrm{mol} \cdot \mathrm{m}^{-2} \cdot \mathrm{s}^{-1}$ had $24 \%, 37 \%$, or $29 \%$ greater overall leaf thickness, palisade parenchyma, or spongy parenchyma layers, respectively, under R LEDs and B fluorescent 
lamps than plants grown under R LEDs alone (Schuerger et al., 1997). Similarly, geranium (Pelargonium zonale) irradiated with $100 \mu \mathrm{mol} \cdot \mathrm{m}^{-2} \cdot \mathrm{s}^{-1}$ of B LED light had $\approx 16 \%$ thicker leaves compared with plants under $\mathrm{R}$ LED light at the same intensity (Fukuda et al., 2008).

Our objective was to quantify how plants acclimate to light environments with different $\mathrm{B}: \mathrm{R}$ ratios, but the same $P P F$ to facilitate the commercial production of young plants with desirable morphological characteristics. We postulated that as the proportion of $B$ light increased, extension growth would decrease, whereas chlorophyll concentration and leaf thickness would increase.

\section{Materials and Methods}

Plant materials. Seeds of tomato 'Early Girl', salvia 'Vista Red', impatiens 'SuperElfin XP Red', and petunia 'Wave Pink' were sown in 128 -cell $(2.7 \times 2.7 \mathrm{~cm} ; 12.0-\mathrm{mL}$ volume) seedling trays by a commercial young plant producer (C. Raker and Sons, Inc., Litchfield, MI). Trays were moved to Michigan State University (East Lansing, MI) within $2 \mathrm{~d}$, and all the seedling trays were then cut into sections that each contained $\geq 20$ seedlings, thinned to one plant per cell, and immediately placed in the lighting treatments.

Light treatments and environment. Six modules that were described by Wollaeger and Runkle (2013) contained dimmable B $($ peak $=446 \mathrm{~nm})$ and $\mathrm{R}($ peaks $=634$ and 664 $\mathrm{nm}$ ) LEDs. The intensities of these three LED types were adjusted to create six light-quality treatments based on an average of six measurements from a spectroradiometer (PS-200; Apogee Instruments, Inc., Logan, UT) made at seedling-tray level at different horizontal positions inside each module. Each module delivered a $P P F$ of $160 \mu \mathrm{mol} \cdot \mathrm{m}^{-2} \cdot \mathrm{s}^{-1}$ that consisted of the following light treatments: $\mathrm{B}_{160}\left(160 \mu \mathrm{mol} \cdot \mathrm{m}^{-2} \cdot \mathrm{s}^{-1}\right.$ of $\mathrm{B}$ and no R light; $100 \% \mathrm{R}), \mathrm{B}_{80}+\mathrm{R}_{80}(50 \% \mathrm{~B}, 50 \% \mathrm{R}), \mathrm{B}_{40}+\mathrm{R}_{120}$ $(25 \% \mathrm{~B}, 75 \% \mathrm{R}), \mathrm{B}_{20}+\mathrm{R}_{140}(12.5 \% \mathrm{~B}, 87.5 \%$ R), $B_{10}+R_{150}(6.2 \% \mathrm{~B}, 93.8 \% \mathrm{R})$, and $\mathrm{R}_{160}$ $(100 \%$ R) (Fig. 1). All treatments that delivered $\mathrm{R}$ light were delivered equally by the two types of R LEDs. The LED modules were placed in a refrigerated growth chamber and the experiment was performed three times. In a separate growth chamber, plants were grown under cool-white fluorescent lamps (F96T12; Philips, Amsterdam, Netherlands) with the same $P P F$ and temperature set points, which served as a control. The flux of photons in the $\mathrm{B}, \mathrm{R}$, and FR wavebands was calculated for the fluorescent lamps and was 33, 43, and $3 \mu \mathrm{mol} \cdot \mathrm{m}^{-2} \cdot \mathrm{s}^{-1}$, respectively. Plants were grown under an 18-h photoperiod (0500 to $2300 \mathrm{HR}$ ) as controlled by a data logger (CR10; Campbell Scientific, Logan, UT). The growth chambers were set at a constant (day/night) $20{ }^{\circ} \mathrm{C}$ to minimize any potentially confounding effect of a diurnal temperature difference on extension growth. In each treatment, air and plant canopy temperature and light intensity were continuously measured as described by
Wollaeger and Runkle (2014), and means are presented in Table 1. Plants were irrigated as needed by subsurface irrigation with a watersoluble fertilizer as described by Wollaeger and Runkle (2014).

Data collection. Ten random plants of each species and treatment were harvested per replication the following number of days after seed sow (rep. 1, 2, 3): tomato $(32,31$, $33)$, impatiens $(33,33,34)$, petunia $(34,35$, $35)$, and salvia $(36,34,37)$. The variability in harvest time among experimental replications was due to availability of labor. The following data were collected at harvest: leaf (at node) number; total leaf area [measured with a leaf area meter (LI-3000; LI-COR, Lincoln, NE)]; fresh shoot, leaf (without petiole), and petiole weight; shoot dry weight (after plants were dried at $\geq 66{ }^{\circ} \mathrm{C}$ for $\geq 5 \mathrm{~d}$ ), and macroscopic flower bud number. A visible leaf that was $\geq 25 \%$ unfolded was counted in leaf number. Stem length was measured by a ruler (from the medium surface to the apical meristem) on all plants except for petunia, which grew as a rosette. The number of leaflets with intumescences was counted on tomato; the physiological disorder did not occur on the other plants. Tomato was also subjectively evaluated for chlorosis by assigning a score from 1 (no chlorosis, $100 \%$ green) to 5 (severe chlorosis, $100 \%$ yellow). Chlorophyll concentration was determined as reported by Wollaeger and Runkle (2013) on the following days after seed sow (rep 1, 2, 3): 29, 31, and 30.

Leaf thickness of tomato and salvia was measured from each treatment on the two largest leaves of each plant on the harvest dates. Three leaflets of each plant were placed in separate plastic bags with deionized water to prevent desiccation until they were sectioned. The leaves were layered, rolled, and inserted into a handheld microtome (MT.5503; Euromex Microscopes Holland, Arnhem, the Netherlands). Nine to eleven cross sections per sampled plant of each species and treatment were sliced and placed with deionized water on a single-frosted precleaned microscope slide $(75 \times 25 \mathrm{~mm}$; Corning Glass Works, Corning, NY) with a 28 g coverslip (VWR Scientific Inc., San

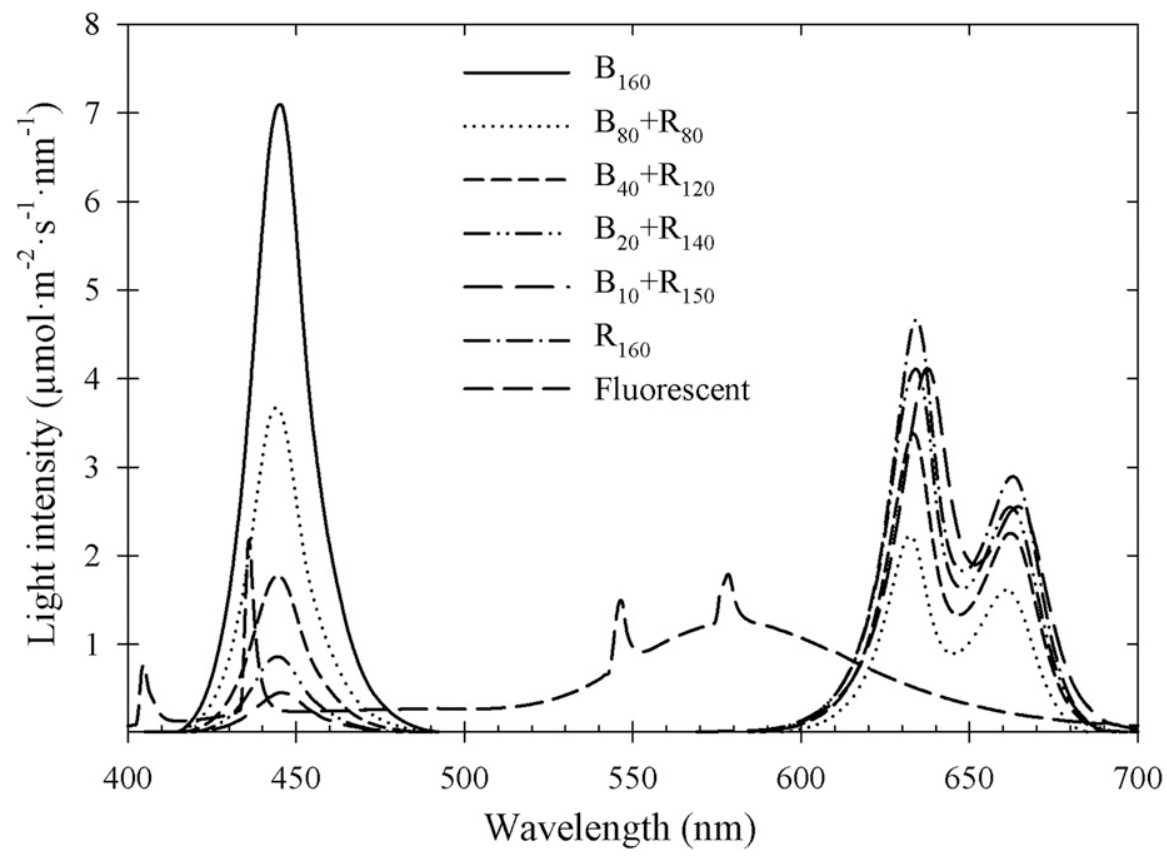

Fig. 1. The spectral distribution of seven light quality treatments delivered by blue (B; 400-500 nm) and red (R; 600-700 nm) LEDs or cool-white fluorescent lamps, each delivering a photosynthetic photon flux of $160 \mu \mathrm{mol} \cdot \mathrm{m}^{-2} \cdot \mathrm{s}^{-1}$. The value after each waveband represents its intensity (in micromole per square meter per second).

Table 1. Actual air and canopy temperatures $\left({ }^{\circ} \mathrm{C}\right)$ as measured by thermocouples and IR sensors for LEDlighting treatments (B: blue, R: red) and one fluorescent lighting treatment. The value after each waveband represents its intensity (in micromole per square meter per second). All temperatures had a SE $\pm 0.1^{\circ} \mathrm{C}$.

\begin{tabular}{|c|c|c|c|c|c|c|}
\hline \multirow[b]{2}{*}{ Light quality treatment } & \multicolumn{2}{|c|}{ Replication 1} & \multicolumn{2}{|c|}{ Replication 2} & \multicolumn{2}{|c|}{ Replication 3} \\
\hline & Air & Canopy & Air & Canopy & Air & Canopy \\
\hline$\overline{\mathrm{B}_{160}}$ & 21.2 & 20.6 & 21.2 & 20.4 & 21.4 & 21.1 \\
\hline $\mathrm{B}_{80}+\mathrm{R}_{80}$ & 20.8 & 21.1 & 20.8 & 20.8 & 21.9 & 20.8 \\
\hline $\mathrm{B}_{40}+\mathrm{R}_{120}$ & 20.6 & 20.4 & 20.9 & 20.3 & 21.4 & 21.3 \\
\hline $\mathrm{B}_{20}+\mathrm{R}_{140}$ & 21.4 & 20.6 & 20.4 & 20.1 & 21.5 & 21.4 \\
\hline $\mathrm{B}_{10}+\mathrm{R}_{150}$ & 21.0 & 20.5 & 20.6 & 20.7 & 21.2 & 21.0 \\
\hline $\mathrm{R}_{160}$ & 20.7 & 20.4 & 20.4 & 20.3 & 21.4 & 21.5 \\
\hline Fluorescent & 21.7 & 21.9 & 21.9 & 21.5 & 21.5 & 21.7 \\
\hline
\end{tabular}


Francisco, CA). Wet-mounted fresh sections were examined under $64 \times$ magnification on an Olympus Stereo microscope (SZH-ILLD; Olympus American Inc., Center Valley, PA). The thickness of the leaf, away from a vein or a midrib, was measured using the ocular micrometer in the viewfinder for each sample while the same magnification was maintained. A conversion factor was determined between the viewfinder reticule in the microscope and a stage micrometer.

Statistical analysis. Data for total leaf area, fresh and dry shoot weight, leaf thickness, and chlorophyll concentration were analyzed with SAS (SAS Institute, Cary, NC) means procedure (PROC MEANS) and mixed model procedure (PROC MIXED). For the count data (leaf number, flower bud number, and chlorosis score), the data were analyzed using the general linear mixed model procedure (PROC GLIMMIX; Poisson distribution). The pdmix 800 program (Arnold M. Saxton, University of Tennessee), that provided pairwise comparisons between treatments using Tukey's honestly significant test at $P \leq 0.05$, was used to analyze all data within all other procedures. For several data parameters, values were calculated and are presented relative to those under fluorescent lamps.

\section{Results}

Leaf number and relative leaf area. In all species, the mean leaf number was similar among treatments and was $10.9,9.8,5.6$, and 11.6 for impatiens, salvia, tomato, and petunia, respectively (Fig. 2). Leaf area was greatest in impatiens and petunia under the fluorescent lamps $\left(27.2\right.$ and $29.0 \mathrm{~cm}^{2}$, respectively), under the $\mathrm{R}_{160}$ treatment in salvia $\left(34.1 \mathrm{~cm}^{2}\right)$, and under the $\mathrm{B}_{20}+\mathrm{R}_{140}$ in tomato $\left(39.9 \mathrm{~cm}^{2}\right)$. Leaf area of plants grown under fluorescent lamps was set to $100 \%$ and leaf area for all LED treatments is presented relative to these values. Leaf area of all plant species under treatment $\mathrm{R}_{160}$ was similar to that of plants under fluorescent lamps. Leaf area of impatiens and salvia under treatment $\mathrm{R}_{160}$ was about twice that of plants grown with $\geq 80 \mu \mathrm{mol} \cdot \mathrm{m}^{-2} \cdot \mathrm{s}^{-1}$ of $\mathrm{B}$ light. Petunia leaf area under treatment $\mathrm{R}_{160}$ was $80 \%$ to $116 \%$ greater than that of plants under treatments $\mathrm{B}_{10}+\mathrm{R}_{150}$ or $\mathrm{B}_{80}+\mathrm{R}_{80}$, respectively. In tomato, there was no significant effect of light quality on leaf area and there was a significant $(P \leq 0.001)$ interaction between light quality and replication (data not shown).

Seedling height. Mean height of salvia and tomato grown under the fluorescent lamps was 51 and $80 \mathrm{~mm}$, respectively, and were similar to those under the $\mathrm{R}_{160}$ treatment. Impatiens was $58 \%$ taller under the $\mathrm{R}_{160}$ treatment than under fluorescent lamps, which were $28 \mathrm{~mm}$ in height. Impatiens, salvia, and tomato with $\geq 10 \mu \mathrm{mol} \cdot \mathrm{m}^{-2} \cdot \mathrm{s}^{-1}$ of B light were $37 \%$ to $48 \%, 29 \%$ to $50 \%$, or $23 \%$ to $49 \%$ shorter than plants under the $\mathrm{R}_{160}$ treatment, respectively. Stem height of impatiens was similar for all other treatments. Salvia grown under treatment $\mathrm{B}_{80}+\mathrm{R}_{80}$ was $22 \%$ to $36 \%$ shorter than plants grown under treatment $\mathrm{B}_{10}+\mathrm{R}_{150}$ or under fluorescent lamps. Similarly, tomato plants under treatment $\mathrm{B}_{80}+\mathrm{R}_{80}$ were $24 \%$ to $26 \%$ shorter than those irradiated with 10 or $20 \mu \mathrm{mol} \cdot \mathrm{m}^{-2} \cdot \mathrm{s}^{-1}$ of B light or those grown under fluorescent lamps.

Fresh shoot weight. The fresh weight of impatiens, salvia, tomato and petunia grown under fluorescent lamps $(1.34,0.86,1.00$, and $1.39 \mathrm{~g}$, respectively) were similar to those grown under $\mathrm{R}_{160}$ for all species. Fresh shoot weight under all LED treatments was calculated relative to those grown under fluorescent lamps (Fig. 3).

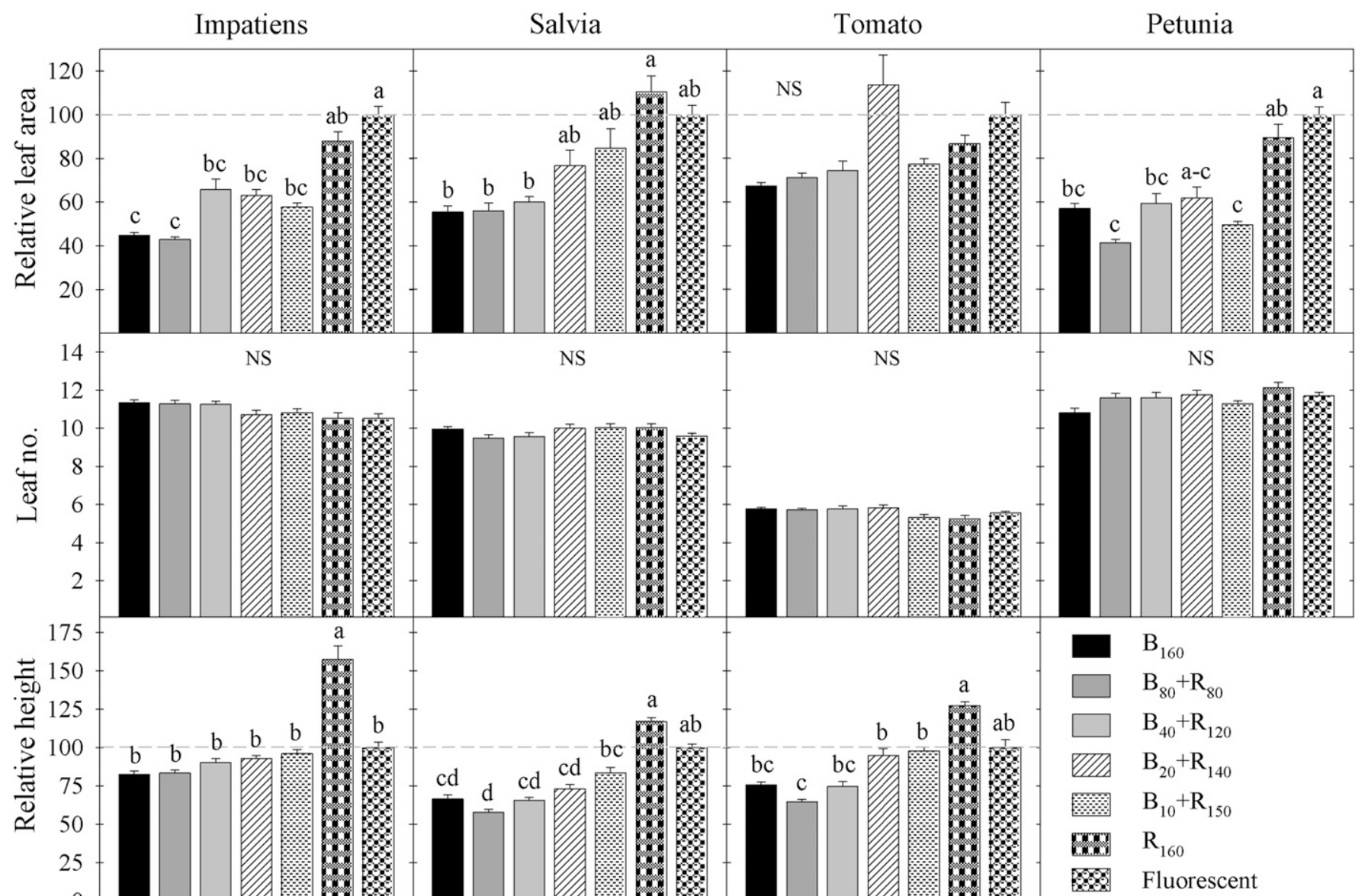

Light quality treatment

Fig. 2. Mean leaf area, leaf number, and height of four seedling crops $(n=30)$ grown under seven light quality treatments delivered by blue $(\mathrm{B} ; 400-500 \mathrm{~nm})$ and red (R; 600-700 nm) LEDs or cool-white fluorescent lamps at the same photosynthetic photon flux. Leaf area and height are presented relative to plants grown under fluorescent lamps. The value after each waveband represents its intensity (in micromole per square meter per second). Means sharing a letter are not statistically different by Tukey's honestly significant difference at $P \leq 0.05$. Error bars indicate SE. 


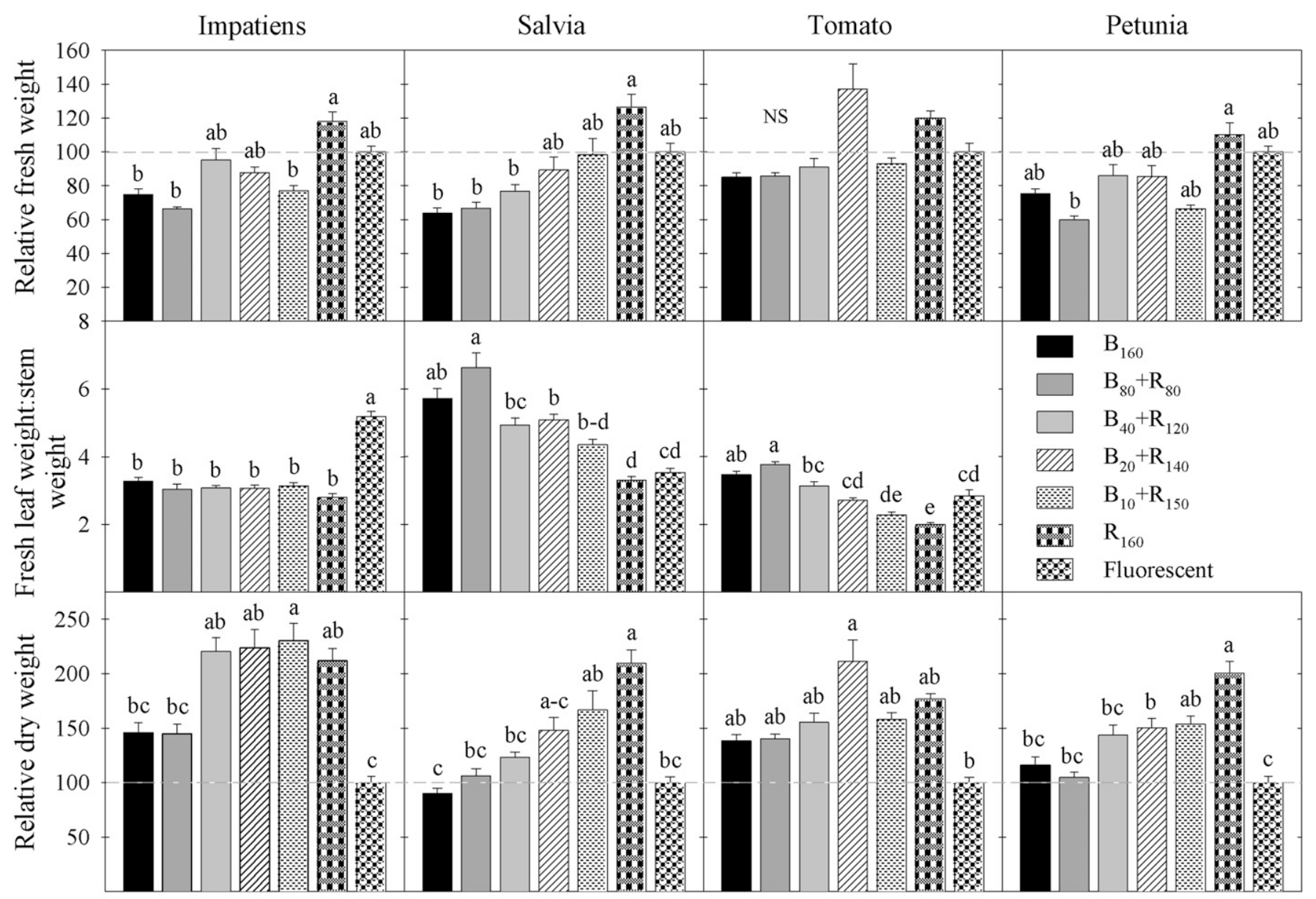

Light quality treatment

Fig. 3. Mean fresh and dry shoot weights for four seedling crops and leaf : stem fresh weight ratio for three seedling crops $(n=30)$ grown under seven light quality treatments delivered by blue (B; 400-500 nm) and red (R; 600-700 nm) LEDs or cool-white fluorescent lamps at the same photosynthetic photon flux. Fresh and dry shoot weights are presented relative to those grown under fluorescent lamps. The leaf: stem fresh weight ratio was not applicable to petunia because it grew as a rosette. The value after each waveband represents its intensity (in micromole per square meter per second). Means sharing a letter are not statistically different by Tukey's honestly significant difference at $P \leq 0.05$. Error bars indicate sE.

Impatiens fresh shoot weight was $53 \%$ to $78 \%$ greater for plants grown under treatment $\mathrm{R}_{160}$ than for those grown under $\geq 80 \mu \mathrm{mol} \cdot \mathrm{m}^{-2} \cdot \mathrm{s}^{-1}$ of $B$ light or under treatment $B_{10}+R_{150}$. Fresh shoot weight of salvia under $\mathrm{R}_{160}$ was $65 \%$ to $98 \%$ greater for plants grown under $\geq 40 \mu \mathrm{mol} \cdot \mathrm{m}^{-2} \cdot \mathrm{s}^{-1}$ of $\mathrm{B}$ light. Petunia under treatment $\mathrm{R}_{160}$ had $84 \%$ greater fresh weight than plants under treatment $\mathrm{B}_{80}+\mathrm{R}_{80}$. The fresh shoot weight of tomato was similar among plants under all treatments, and there was a significant $(P \leq 0.001)$ interaction between light quality and replication (data not shown).

Dry shoot weight. Dry weight of impatiens, salvia, tomato, and petunia $(73,66$, 105 , and $144 \mathrm{mg}$, respectively) grown under fluorescent lamps were among the least when compared with all LED treatments. Dry weight under all LED treatments was calculated relative to those grown under fluorescent lamps. Dry weight was greatest for salvia and petunia under the $\mathrm{R}_{160}$ treatment (221 and $133 \mathrm{mg}$, respectively), for impatiens under treatment $\mathrm{B}_{10}+\mathrm{R}_{150}(167 \mathrm{mg})$, and for tomato under treatment $\mathrm{B}_{20}+\mathrm{R}_{140}(304 \mathrm{mg})$. Dry weight of impatiens was essentially the same under treatments that delivered 0 to
$40 \mu \mathrm{mol} \cdot \mathrm{m}^{-2} \cdot \mathrm{s}^{-1}$ of B light, and all of those were more than twice that of plants grown under fluorescent lamps. Salvia showed a trend for dry weight that was similar to but stronger than that for fresh shoot weight. Plants grown under treatment $\mathrm{R}_{160}$ had $70 \%$ to $133 \%$ greater dry weight than plants grown with $\geq 40 \mu \mathrm{mol} \cdot \mathrm{m}^{-2} \cdot \mathrm{s}^{-1}$ of B light or plants grown under fluorescent lamps. Tomato grown under $\mathrm{B}_{20}+\mathrm{R}_{140}$ had $112 \%$ greater dry weight than plants grown under fluorescent lamps, but it was similar among the other treatments. Dry weight of petunia under treatment $\mathrm{R}_{160}$ was $33 \%$ to $91 \%$ greater than that of plants under $\geq 20 \mu \mathrm{mol} \cdot \mathrm{m}^{-2} \cdot \mathrm{s}^{-1}$ of B light.

Leaf:stem fresh weight. Salvia and tomato had a decreasing leaf:stem fresh weight ratio with increasing percentage of $\mathrm{R}$ light. Plants of both species had a relatively high leaf:stem fresh weight ratio under treatments with $\geq 80 \mu \mathrm{mol} \cdot \mathrm{m}^{-2} \cdot \mathrm{s}^{-1}$ of B light but a relatively low ratio in treatment $R_{160}$. The leaf:stem fresh weight of impatiens was similar among treatments except for plants grown under fluorescent lighting, which had a $58 \%$ to $85 \%$ greater leaf:stem weight ratio.
Chlorophyll concentration. Salvia, tomato, and petunia had the greatest chlorophyll concentration under the fluorescent lamps $(183,142$, and $138 \mathrm{mg} \mathrm{Chl} / \mathrm{g}$ fresh tissue, respectively) (Fig. 4). Impatiens grown under treatment $\mathrm{R}_{160}(87.9 \mathrm{mg} \mathrm{Chl} / \mathrm{g}$ fresh tissue) had a similar chlorophyll concentration to those grown under fluorescent lamps. Chlorophyll concentration under all LED treatments was calculated relative to values for those grown under fluorescent lamps. Impatiens, salvia, tomato, and petunia had $33 \%$ to $44 \%, 28 \%$ to $46 \%, 51 \%$ to $131 \%$, and $47 \%$ to $145 \%$ greater concentration of chlorophyll under fluorescent lamps, respectively, than plants under all other treatments except impatiens under treatment $\mathrm{R}_{160}$.

Leaf thickness. Leaves of salvia and tomato were among the thinnest ( 0.18 and 0.17 $\mathrm{mm}$, respectively) when plants were grown under fluorescent lamps. Leaf thickness of all LED treatments was calculated relative to that of plants grown under fluorescent lamps. Salvia leaves were thickest under the $\mathrm{B}_{160}$ treatment $(0.33 \mathrm{~mm})$, whereas tomato leaf thickness was the greatest under treatment $\mathrm{B}_{40}+\mathrm{R}_{120}(0.31 \mathrm{~mm})$. Leaves of salvia were 


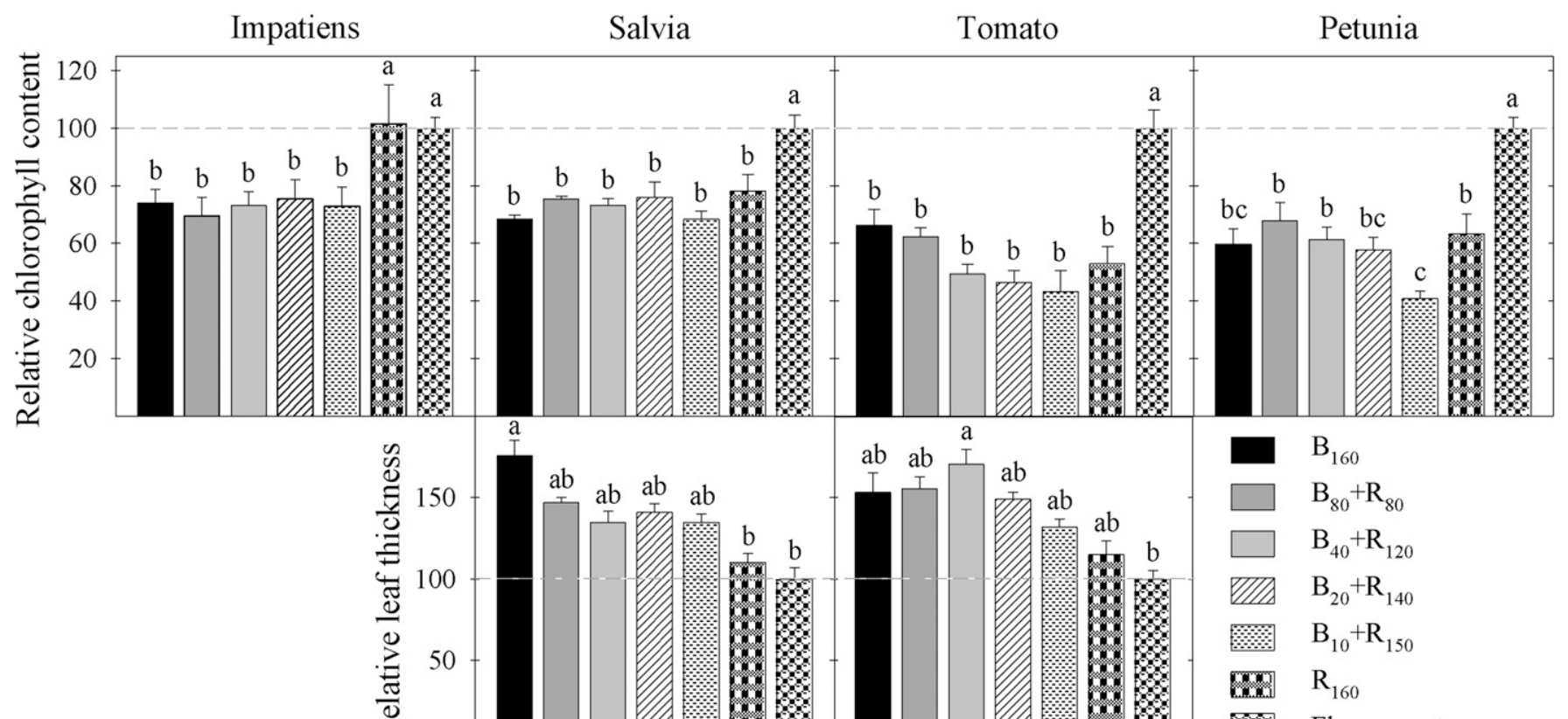

Light quality treatment

Fig. 4. Mean chlorophyll concentrations for four seedling crops and leaf thickness for salvia and tomato $(n=30)$ grown in seven light treatments delivered by blue (B; 400-500 nm) and red (R; 600-700 nm) LEDs or cool-white fluorescent lamps at the same photosynthetic photon flux. Values are presented relative to plants grown under fluorescent lamps. The value after each waveband represents its intensity (in micromole per square meter per second). Means sharing a letter are not statistically different by Tukey's honestly significant difference at $P \leq 0.05$. Error bars indicate sE.

$37 \%$ to $43 \%$ thinner in plants grown without B light or plants grown under fluorescent lamps compared with that of plants grown under $100 \%$ B light. Tomato leaves were $41 \%$ thinner under fluorescent lamps than under the treatment with $25 \%$ B light.

Chlorosis score, intumescences, and flower bud number. Tomato developed chlorosis, intumescences, or both in some lighting treatments, whereas all other plants developed without any physiological disorders. The subjective chlorosis score generally increased (i.e., chlorosis became more severe) as the percentage of B light decreased (Fig. 5). Tomato grown under only B light or fluorescent lamps did not develop intumescences but it became more common with lower percentages of B light. Impatiens was the only plant that had visible flower buds at the end of the treatments. Impatiens generally developed more flower buds under progressively more B light. For example, under only B light there were $59 \%, 177 \%$, or $535 \%$ more flower buds than under treatments with 20,10 , or $0 \mu \mathrm{mol} \cdot \mathrm{m}^{-2} \cdot \mathrm{s}^{-1}$ of $\mathrm{B}$ light, respectively. Impatiens grown under fluorescent lamps developed a number of flower buds similar to that of plants grown with $10 \mu \mathrm{mol} \cdot \mathrm{m}^{-2} \cdot \mathrm{s}^{-1}$ of B light.

\section{Discussion}

Plants can acclimate to and thus exploit a particular light quality environment by modifying leaf size and shape (anatomical changes), chlorophyll density (physiological changes), and/or photosynthesis reactions [biochemical changes, e.g., biosynthesis of ribulose bisphosphate carboxylase/oxygenase
(Rubisco)] (Senger and Bauer, 1987). Our objective was to quantify how plant morphology changes in response to light environments with different $\mathrm{B}: \mathrm{R}$ ratios. Plants acclimate to being grown under only $R$ light, in the absence of B and FR light, by increasing leaf expansion and developing characters analogous with the shade-avoidance response, including increased chlorophyll content and stem length and decreased leaf thickness (Blackman and Wilson, 1951; Eskins, 1992; Franklin and Whitelam, 2005; Grime and Jeffrey, 1965; Jarvis, 1964). In our study, leaf area of impatiens, salvia, and petunia grown without B light was much greater than that of plants grown with B light. Similarly, leaf area was $47 \%$ to $130 \%$ greater in tomato, impatiens, petunia, and salvia grown under only R light compared with the same $P P F$ that included $\geq 25 \% \quad B$ light (Wollaeger and Runkle, 2014). Interestingly, in this study, leaf area of all species under only $\mathrm{R}$ light was similar to that of plants under fluorescent lamps even though the fluorescent lamps emitted $33 \mu \mathrm{mol} \cdot \mathrm{m}^{-2} \cdot \mathrm{s}^{-1}$ of $\mathrm{B}$ light, which was more than that of the $\mathrm{B}_{20}+\mathrm{R}_{140}$ treatment. Similarly, lettuce grown at a $P P F$ of 300 $\mu \mathrm{mol} \cdot \mathrm{m}^{-2} \cdot \mathrm{s}^{-1}$ had a $44 \%$ greater leaf area under R fluorescent light than under B fluorescent light, whereas it was similar under $\mathrm{R}$, $\mathrm{R}+\mathrm{B}$, or white fluorescent light (OhashiKaneko et al., 2007). In contrast, leaf area of cotton (Gossypium hirsutum) was similar between plants grown under $100 \% \mathrm{~B}$ or R LEDs (peaks of 460 or $660 \mathrm{~nm}$ ), whereas both were greater than that of plants under $\mathrm{B}+\mathrm{R}(1: 3)$ at the same $P P F$ of $50 \mu \mathrm{mol} \cdot \mathrm{m}^{-2} \cdot \mathrm{s}^{-1}$ (Li et al., 2010). These contrasting results with cotton could at least partially be attributed to the low
$P P F$, which was less than half of that in our study.

Plants grown in environments with B light can have less biomass accumulation and thicker stems than those under only R light, but responses have varied among species studied (Johkan et al., 2010; Schuerger et al., 1997; Wollaeger and Runkle, 2014). In this study, fresh shoot weight of impatiens, petunia, and salvia was $53 \%$ to $98 \%$ greater under treatments without B LED light than with $\geq 50 \%$ B light. Biomass allocation between leaves and stems was similar among all treatments except those of plants grown under fluorescent lighting for the shade-tolerant impatiens, whereas leaf biomass of the shade-intolerant salvia and tomato was proportionately greater under light with lower $\mathrm{B}: \mathrm{R}$ ratios. Although fresh shoot weight was similar among treatments grown under only $\mathrm{R}$ light or fluorescent lamps, plants grown under only R light had $33 \%$ to $133 \%$ greater dry weight than plants grown under fluorescent lamps. Thus, plants grown under only $\mathrm{R}$ light fixed more carbon than those under fluorescent light, and apparently had a higher water content. Contrasting results have been reported in lettuce and komatsuna; lettuce had $28 \%$ greater shoot dry weight under white than $\mathrm{R}$ fluorescent light, whereas komatsuna had $43 \%$ greater dry weight under $\mathrm{R}$ light than white light (Ohashi-Kaneko et al., 2006). In strawberry, fresh shoot weight was $42 \%$ greater under only $\mathrm{R}$ (peak $=660 \mathrm{~nm}$ ) than only B (peak $=450 \mathrm{~nm})$ LED light at a $P P F$ of $45 \mu \mathrm{mol} \cdot \mathrm{m}^{-2} \cdot \mathrm{s}^{-1}$ (Nhut et al., 2003).

In protected climates, the shade-avoidance response can be prevented by low-density spacing of plants to avoid mutual shading 


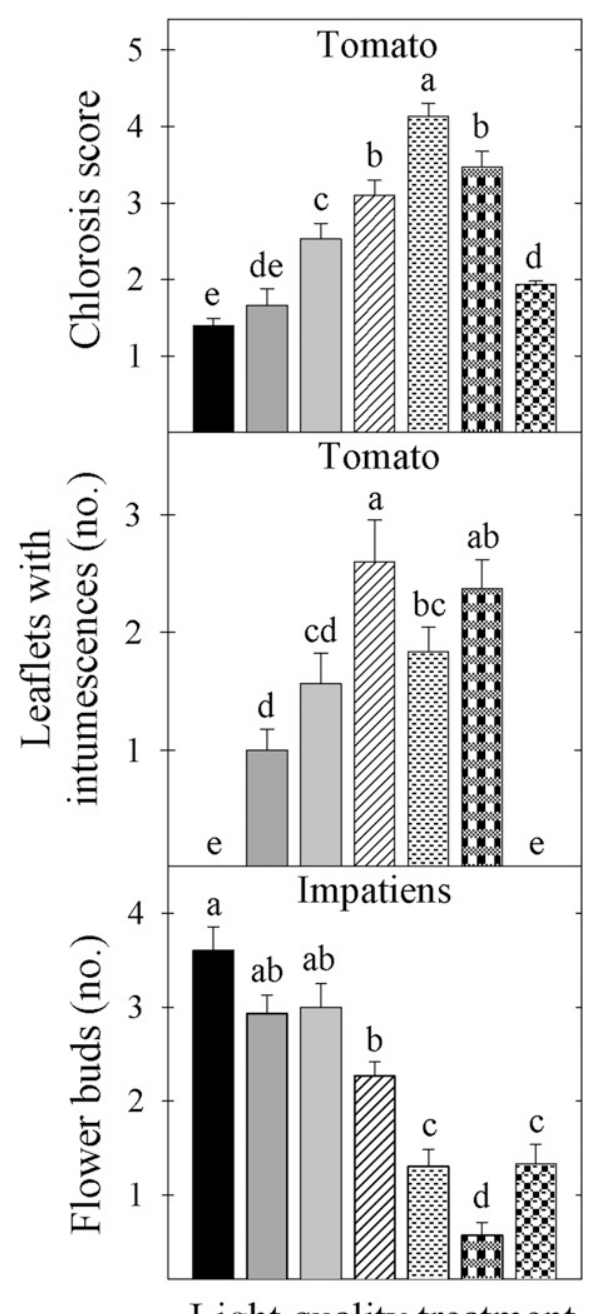

Light quality treatment

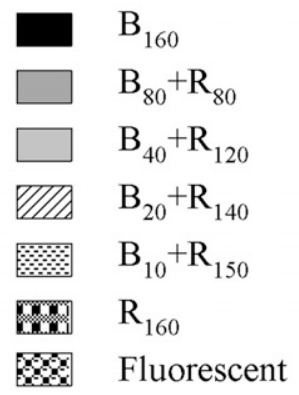

Fig. 5. Mean chlorosis score and number of leaves exhibiting intumescences for tomato and flower bud number for impatiens $(n=30)$ under seven light quality treatments delivered by blue (B; 400-500 nm) and red (R; 600-700 nm) LEDs or cool-white fluorescent lamps at the same photosynthetic photon flux. Chlorosis score: $1=$ least chlorotic, $5=$ most chlorotic. The value after each waveband represents its intensity (in micromole per square meter per second). Means sharing a letter are not statistically different by Tukey's honestly significant difference at $P \leq 0.05$. Error bars indicate SE.

and by delivering B light or light with a high R:FR. Phytochrome and cryptochrome photoreceptors perceive $\mathrm{R}$ and FR light or $\mathrm{B}$ light and ultraviolet-A (320-390 $\mathrm{nm})$ radiation, respectively, and mediate extension growth (Liu et al., 2011a; Smith, 2000; Stapleton,
1992). Because few FR photons were present in the six LED lighting treatments, the stem elongation inhibition we observed from as little as $6.3 \%$ B light could be attributed to the B-light-stimulated cryptochrome receptors, which are most stimulated by wavelengths between 390 and $480 \mathrm{~nm}$ (Liu et al., 2011a; Ahmad et al., 2002). In Arabidopsis, CRY1 genes regulate extension growth of seedlings by altering downstream expression of other genes, such as COP1 and HY5 (Jiao et al., 2007; Liu et al., 2011a; Yang et al., 2005). CRY1 consequently regulates phytohormone distribution of gibberellic acid (Liu et al., 2011b). The smallest quantity of B light delivered in our treatments was $10 \mu \mathrm{mol} \cdot \mathrm{m}^{-2} \cdot \mathrm{s}^{-1}$, which was apparently adequate to stimulate cryptochrome receptors. Only $5 \mu \mathrm{mol} \cdot \mathrm{m}^{-2} \cdot \mathrm{s}^{-1}$ of B light was sufficient to stimulate cryptochrome responses in Arabidopsis and barley (Hordeum vulgare) (Christopher and Mullet, 1994; Hogewoning et al., 2010; Mochizuki et al., 2004). All plants in our study with $\geq 25 \%$ B light were of similar height, which suggests that cryptochrome became saturated at $\approx 40 \mu \mathrm{mol} \cdot \mathrm{m}^{-2} \cdot \mathrm{s}^{-1}$ of B light. In a previous study, impatiens, tomato, salvia, and petunia grown under $\geq 25 \%$ B light were $41 \%$ to $57 \%$ shorter than those under only $\mathrm{R}$ light (Wollaeger and Runkle, 2014). In contrast, marigold and salvia grown under B LEDs $\left(\right.$ peak $=440 \mathrm{~nm}$ ) at a $P P F$ of $90 \mu \mathrm{mol} \cdot \mathrm{m}^{-2} \cdot \mathrm{s}^{-1}$ were about twice as tall as plants grown under only R LEDs (peak $=650 \mathrm{~nm}$ ) at the same intensity (Heo et al., 2002). We cannot explain this discrepancy.

Thinner leaves, also a characteristic of the shade-avoidance response, typically develop under a low R:FR ratio or light deficient in B (Fukuda et al., 2008; Schuerger et al., 1997). In this study, leaves of salvia were $37 \%$ to $43 \%$ thinner in plants grown without B light or under fluorescent lamps than in plants grown under $100 \%$ B light; however, tomato leaf thickness was similar under the different $B: R$ ratios. The increase in salvia leaf thickness with increasing percentage of $B$ light is consistent with that reported for cucumber and geranium (Fukuda et al., 2008; Schuerger et al., 1997). Plants grown under white fluorescent lamps had relatively thin leaves, contributing to the relatively low dry weight and high water content, compared with those grown under combinations of R and B LEDs. Leaves could be thinner under fluorescent light because of the high proportion of $G$ light, which is not absorbed by leaves as much as B or R light. Light quality can also influence leaf orientation; Fukuda et al. (2008) showed that irradiating the adaxial surface of geranium (Pelargonium zonale) leaves with light from $\mathrm{B}+\mathrm{R}$ LEDs produced leaves that were $20 \%$ more upright than those irradiated with only $\mathrm{R}$ light. Plants in this study grown under fluorescent lamps had visually more upright leaves than those grown under our LED treatments, although this data was not recorded.

Plants acclimate to a high $\mathrm{B}: \mathrm{R}$ ratio by increasing chlorophyll synthesis, as mediated by cryptochrome (Folta and Childers, 2008). Plants in this study had $28 \%$ to $145 \%$ greater chlorophyll concentration under fluorescent lamps, which emitted 54\% G light, than under all treatments except for impatiens grown without B light. This suggests that more resources were allocated to carbonassimilating capacity per leaf in plants grown under fluorescent lamps than those grown under only $\mathrm{R}$ light. This concept is in agreement with Reich et al. (1998), who concluded that leaf structure and size can influence net photosynthetic capacity. Petunia had relatively low chlorophyll content when plants were grown under $25 \%$ B light. Similarly, the concentration of chlorophyll in salvia and tomato was relatively high under fluorescent light and relatively low under all other treatments, but it was similar among all treatments for impatiens and petunia (Wollaeger and Runkle, 2014). This suggests that plants grown under fluorescent lamps could have acclimated to the high percentage of $\mathrm{G}$ light, which is absorbed by chlorophyll less than R or B light, by increasing chlorophyll biosynthesis, decreasing chlorophyll degradation, or both, to maximize photosynthetic capacity. Other studies have reported similar chlorophyll concentrations between LED light treatments in cherry tomato and lettuce (Liu et al., 2011b). For example, chlorophyll content per leaf area of cherry tomato was similar among LED treatments delivering $\mathrm{B}, \mathrm{G}, \mathrm{R}, \mathrm{R}+\mathrm{B}(1: 1)$, or $\mathrm{R}+\mathrm{B}+\mathrm{G}$ $(3: 3: 1$; peaks $=650,450$, and $520 \mathrm{~nm}$, respectively) at the same PPF (Liu et al., $2011 b$ ). In contrast to our results, chlorophyll concentration of lettuce was similar among combinations of cool-white fluorescent and $\mathrm{R}$ $($ peak $=658 \mathrm{~nm})$ or B $($ peak $=476 \mathrm{~nm})$ LED light at the same $P P F$ (Li and Kubota, 2009).

Intumescences have been correlated with environments deficient in B or FR light or especially ultraviolet-B $(280-315 \mathrm{~nm})$ (Jenkins, 2009) radiation, particularly on plants in the Solanaceae (Craver et al., 2014b; Lang and Tibbitts, 1983; Massa et al., 2008; Morrow and Tibbitts, 1988; Nilsen, 1971). Tomato grown under only B light or fluorescent lamps did not develop intumescences, which became more prevalent as the B:R ratio decreased. Similarly, wild tomato ( $S$. hirsutum) developed intumescences on $63 \%$ of the leaf area surface when under $\mathrm{R}$ fluorescent lamps, whereas they were absent under B fluorescent lamps at a $P P F$ of $25 \mu \mathrm{mol} \cdot \mathrm{m}^{-2} \cdot \mathrm{s}^{-1}$ (Morrow and Tibbitts, 1988). Intumescences develop as plant cells divide and especially when they enlarge due to a deficiency of ultraviolet-B in some cultivars that are more prone to the physiological disorder (Craver et al., 2014a). Still under investigation, a current theory suggests that intumescences develop on tomato and sweetpotato plants when grown in an environment deficient in ultraviolet-B because of reduced inhibitory actions against the plant hormone, auxin. When auxin is not sufficiently degraded, especially in the lower canopy, cell expansion remains unchecked, leading to the formation of intumescences (Craver et al., 2014b). Intumescence development can also be influenced by other 
environmental factors such as diurnal temperature fluctuations (Massa et al., 2008). Thus, intumescence development may have been especially severe because a constant day/night temperature was delivered in this research.

Early flowering can be induced in some species by B light. Impatiens under only B light developed significantly more flower buds than with $\leq 20 \mu \mathrm{mol} \cdot \mathrm{m}^{-2} \cdot \mathrm{s}^{-1}$ of B light. $C R Y 2$ cryptochrome receptors can stimulate flowering by promoting downstream flowering genes, including $C O$ and $F T$ (Chaves et al., 2011; El-Assal et al., 2003). This suggests that increasing stimulation of $C R Y 2$ by increasing B light caused impatiens to flower earlier than do treatments with little or no B light. Increased flower number in light that contains $\mathrm{B}$, compared with that without $\mathrm{B}$, has been reported in other ornamental annual plants. For example, marigold and salvia produced $43 \%$ or $100 \%$ more flower buds, respectively, under $\mathrm{B}+\mathrm{R}$ (peaks $=440$ and $650 \mathrm{~nm}$, respectively) LED light compared with those grown under fluorescent light at the same intensity (Heo et al., 2006). In contrast, marigold and salvia grown under $\mathrm{B}$ or R LEDs (peaks $=440$ and $650 \mathrm{~nm}$, respectively) at a $P P F$ of $90 \mu \mathrm{mol} \cdot \mathrm{m}^{-2} \cdot \mathrm{s}^{-1}$ developed a similar number of flower buds, whereas plants under either treatment had $77 \%$ to $86 \%$ fewer flower buds than those under fluorescent lamps (Heo et al., 2002). Similarly, impatiens grown under $100 \%$ B light had 71 times more flower buds than those grown under only $\mathrm{R}$ light (Wollaeger and Runkle, 2014). We ended experiments before salvia, tomato, or petunia had visible flower buds, so we do not know whether B light would have had effects on flowering similar to that in impatiens.

We conclude that plants acclimate to only $\mathrm{R}$ light by increasing leaf expansion and stem elongation, whereas plant responses to B light include inhibited extension growth and, in some cases, greater leaf thickness and chlorophyll concentration. Subsequently, plants under only R light accumulated more biomass than those of other treatments in part because of the increased leaf surface area for light capture. About $6 \%$ to $13 \%$ B light was apparently sufficient to stimulate (presumably cryptochrome) photoreceptors that inhibited extension growth, thereby reducing leaf size and biomass accumulation. Therefore, including as little as $10 \mu \mathrm{mol} \cdot \mathrm{m}^{-2} \cdot \mathrm{s}^{-1}$ of $\mathrm{B}$ light in an R-dominant background can elicit desirable growth responses for the production of propagules, herbs, and microgreens, and for other situations in which compact growth is desired.

\section{Literature Cited}

Ahmad, M., N. Grancher, M. Heil, R.C. Black, B. Giovani, P. Galland, and D. Lardemer. 2002. Action spectrum for cryptochrome-dependent hypocotyl growth inhibition in Arabidopsis. Plant Physiol. 129:774-785.

Blackman, G.E. and G.L. Wilson. 1951. Physiological and ecological studies in the analysis of plant environment. Ann. Bot. (Lond.) 15:373408.

Cashmore, A.R., J.A. Jarillo, Y.J. Wu, and D. Liu. 1999. Cryptochromes: Blue light receptors for plants and animals. Science 284:760-765.

Chaves, I., R. Pokorny, M. Byrdin, N. Hoang, T. Ritz, K. Brettel, L.-O. Essen, G.T.J. van der Horst, A. Batschauer, and M. Ahmad. 2011. The cryptochromes: Blue light photoreceptors in plants and animals. Annu. Rev. Plant Biol. 62:335-364.

Christopher, D.A. and J.E. Mullet. 1994. Separate photosensory pathways co-regulate blue-light/ ultraviolet-A-activated $p s b D-p s b C$ transcription and light-induced D2 and CP43 degradation in barley (Hordeum vulgare) chloroplasts. Plant Physiol. 104:1119-1129.

Craver, J.K., C.T. Miller, K.A. Williams, and D.L. Boyle. 2014a. Characterization and comparison of lesions on ornamental sweetpotato 'Blackie', tomato 'Maxifort', interspecific geranium 'Caliente Coral', and bat-faced cuphea 'Tiny Mice'. J. Amer. Soc. Hort. Sci. 139:603-615.

Craver, J.K., C.T. Miller, K.A. Williams, and N.M. Bello. 2014b. Ultraviolet radiation affects intumescence development in ornamental sweetpotato (Ipomoea batatas). HortScience 49:1277-1283.

El-Assal, S.E.D., C. Alonso-Blanco, A.J.M. Peeters, C. Wagemaker, J.L. Weller, and M. Koornneef. 2003. The role of cyptochrome 2 in flowering in Arabidopisis. Plant Physiol. 133:1504-1516.

Eskins, K. 1992. Light-quality effects of Arabidopsis development: Red, blue, and far-red regulation of flowering and morphology. Physiol. Plant. 86:439-444.

Fan, X.-X., Z.-G. Xu, X.-Y. Liu, C.-M. Tang, L.-W. Wang, and X.-L. Han. 2013. Effects of light intensity on the growth and leaf development of young tomato plants grown under a combination of red and blue light. Sci. Hort. 153:50-55.

Folta, K.M. and K.S. Childers. 2008. Light as a growth regulator: Controlling plant biology with narrow-bandwidth solid-state lighting systems. HortScience 43:1957-1964.

Franklin, K. and G. Whitelam. 2005. Phytochromes and shade-avoidance responses in plants. Ann. Bot. (Lond.) 96:169-175.

Fukuda, N., M. Fujita, Y. Ohta, S. Sase, S. Nishimura, and H. Ezura. 2008. Directional blue light irradiation triggers epidermal cell elongation of abaxial side resulting in inhibition of leaf epinasty in geranium under red light conditions. Sci. Hort 115:176-182.

Goins, G.D., N.C. Yorio, M.M. Sanwo, and C.S. Brown. 1997. Photomorphogenesis, photosynthesis, and seed yield of wheat plants grown under red light-emitting diodes (LEDs) with and without supplemental blue lighting. J. Expt. Bot. 48:1407-1413.

Grime, J.P. and D.W. Jeffrey. 1965. Seedling establishment in vertical gradients of sunlight. J. Ecol. 53:621-642.

Hendriks, L. and E. Ueber. 1995. Alternative methods of regulating the elongation growth of ornamental plants: A current assessment. Acta Hort. 378:159-167.

Heo, J., C. Lee, D. Chakrabarty, and K. Paek. 2002. Growth responses of marigold and salvia bedding plants as affected by monochromatic or mixture radiation provided by light-emitting diode (LED). Plant Growth Regulat. 38:225230.

Heo, J.W., C.W. Lee, and K.Y. Paek. 2006. Influence of mixed LED radiation on the growth of annual plants. J. Plant Biol. 49:286-290.

Hogewoning, S.W., G. Trouwborst, H. Maljaars, H. Poorter, W. van Ieperen, and J. Harbinson. 2010. Blue light dose-responses of leaf photosynthesis, morphology, and chemical composition of Cucumis sativus grown under different combinations of red and blue light. J. Expt. Bot. 61:3107-3117.

Horwitz, B.A., W.F. Thompson, and W.R. Briggs. 1988. Phytochrome regulation of greening in Pisum: Chlorophyll accumulation and abundance of messenger-RNA for the light-harvesting chlorophyll A/B binding proteins. Plant Physiol. 86:299-305

Jarvis, P.G. 1964. The adaptability to light intensity of seedlings of Quercus patraea. J. Ecol. 52:545-571

Jenkins, G.I. 2009. Signal transduction in responses to UV-B radiation. Annu. Rev. Plant Biol. 60:407-431.

Jiao, Y., O.S. Lau, and X.W. Deng. 2007. Lightregulated transcriptional networks in higher plants. Nat. Rev. Genet. 8:217-230.

Johkan, M., K. Shoji, F. Goto, S.-N. Hashida, and T. Yoshihara. 2010. Blue light-emitting diode light irradiation of seedlings improves seed quality and growth after transplanting in red leaf lettuce. HortScience 45:1809-1814.

Lang, S.P. and T.W. Tibbitts. 1983. Factors controlling intumescence development on tomato plants. J. Amer. Soc. Hort. Sci. 108:93-98.

Li, H., Z. Xu, and C. Tang. 2010. Effect of lightemitting diodes on growth and morphogenesis of upland cotton (Gossypium hirsutum L.) plantlets in vitro. Plant Cell Tissue Organ Cult. 103:155-163.

Li, J., S. Hikosaka, and E. Goto. 2011. Effects of light quality and photosynthetic photon flux on growth and carotenoid pigments in spinach (Spinacia oleracea L.). Acta Hort. 907:105110.

Li, Q. and C. Kubota. 2009. Effects of supplemental light quality on growth and phytochemicals of baby leaf lettuce. Environ. Exp. Bot. 67:5964.

Li, Z., S. Wakao, B.B. Fischer, and K.K. Niyogi. 2009. Sensing and responding to excess light. Annu. Rev. Plant Biol. 60:239-260.

Lichtenthaler, H.K., C. Buschmann, M. Doll, H. Fietz, T. Bach, U. Kozel, D. Meier, and U. Rahmsdorf. 1981. Photosynthetic activity, chloroplast ultrastructure, and leaf characteristics of high-light and low-light plants and of sun and shade leaves. Photosynth. Res. 2:115-141.

Liu, H., B. Liu, C. Zhao, M. Pepper, and C. Lin. 2011a. The action mechanisms of plant cryptochromes. Trends Plant Sci. 16:684-691.

Liu, X.Y., T.T. Chang, S.R. Guo, Z.G. Xu, and J. Li. 2011b. Effect of light quality of LED on growth and photosynthetic character in cherry tomato seedling. Acta Hort. 907:325-330.

Massa, G.D., H.H. Kim, R.M. Wheeler, and C.A Mitchell. 2008. Plant productivity in response to LED lighting. HortScience 43:1951-1956.

McCree, K.J. 1972. The action spectrum, absorbance and quantum yield of photosynthesis in crop plants. Agr. Meteorol. 9:191-216.

Mitchell, C., A.-J. Both, M. Bourget, J. Burr, C. Kubota, R. Lopez, R. Morrow, and E. Runkle. 2012. LEDs: The future of greenhouse lighting! Chron. Hort. 52:6-11.

Mochizuki, T., Y. Onda, E. Fujiwara, M. Wada, and Y. Toyoshima. 2004. Two independent light signals cooperate in the activation of the plastid $p s b D$ blue light-responsive promoter in Arabidopsis. FEBS Lett. 571:26-30.

Morrow, R.C. and T.W. Tibbitts. 1988. Evidence for involvement of phytochrome in tumor development in plants. Plant Physiol. 88:1110 1114.

Nhut, D.T., T. Takamura, H. Watanabe, K. Okamoto, and M. Tanaka. 2003. Responses of strawberry 
plantlets cultured in vitro under superbright red and blue light-emitting diodes (LEDs). Plant Cell Tissue Organ Cult. 73:43-52.

Nilsen, K.N. 1971. Plant responses to nearultraviolet light. HortScience 6:26-29.

Ohashi-Kaneko, K., M. Takase, N. Kon, K. Fujiwara, and K. Kurata. 2007. Effect of light quality on growth and vegetable quality in leaf lettuce, spinach, and komatsuna. Envrion. Control Biol. 45:189-198.

Ohashi-Kaneko, K., R. Matsuda, E. Goto, K. Fujiwara, and K. Kurata. 2006. Growth of rice plants under red light with or without supplemental blue light. Soil Sci. Plant Nutr. 52:444-452.

Parks, B.M., K.M. Folta, and E.P. Spalding. 2001. Photocontrol of stem growth. Curr. Opin. Plant Biol. 4:436-440.

Reich, P.B., D.S. Ellsworth, and M.B. Walters. 1998. Leaf structure (specific leaf area) modulates photosynthesis-nitrogen relations: Evidence from within and across species and functional groups. Funct. Ecol. 12:948-958.

Saebo, A., T. Krekling, and M. Appelgren. 1995. Light quality affects photosynthesis and leaf anatomy of birch plantlets in vitro. Plant Cell Tissue Organ Cult. 41:177-185.
Sager, J.C., W.O. Smith, J.L. Edwards, and K.L. Cyr. 1988. Photosynthetic efficiency and phytochrome photoequilibria determination using spectral data. Trans. Amer. Soc. Agr. Eng. 31:1882-1889.

Senger, H. and B. Bauer. 1987. The influence of light quality on adaptation and function of the photosynthetic apparatus. Photochem. Photobiol. 45(Suppl 1):939-946.

Schuerger, A.C., C.S. Brown, and E.C. Stryjewski. 1997. Anatomical features of pepper plants (Capsicum annuum L.) grown under lightemitting diodes supplemented with blue or far-red light. Ann. Bot. (Lond.) 79:273-282.

Sellaro, R., M. Crepy, S.A. Trupkin, E. Karayekov, A.S. Buchovsky, C. Rossi, and J.J. Casal. 2010. Cryptochrome as a sensor of the blue/green ratio of natural radiation in Arabidopsis. Plant Physiol. 154:401-409.

Smith, H. 2000. Phytochromes and light signal perception by plants-An emerging synthesis. Nature 407:585-591.

Stapleton, A.E. 1992. Ultraviolet radiation and plants: Burning questions. Plant Cell 4:1353-1358.

Tennessen, D.J., E.L. Singsaas, and T.D. Sharkey. 1994. Light-emitting diodes as a light source for photosynthesis research. Photosynth. Res. 39:85-92.

Valverde, F., A. Mouradov, W. Soppe, D. Ravenscroft, A. Samach, and G. Coupland. 2004. Photoreceptor regulation of $\mathrm{CON}$ STANS protein in photoperiodic flowering. Science 303:1003-1006.

Wollaeger, H.M. and E.S. Runkle. 2013. Growth responses of ornamental annual seedlings under different wavelengths of red light provided by light-emitting diodes. HortScience 48:14781483.

Wollaeger, H.M. and E.S. Runkle. 2014. Growth of impatiens, petunia, salvia, and tomato seedlings under blue, green, and red light-emitting diodes. HortScience 49:734-740.

Yang, J., R. Lin, J. Sullivan, U. Hoecker, B. Liu, L. Xu, X.W. Deng, and H. Wang. 2005. Light regulates COP1-mediated degradation of HFR1, a transcription factor essential for light signaling in Arabidopsis. Plant Cell 17:804821.

Yang, Y.T., P. Xiao, and Q.C. Yang. 2011. Effects of LED light quality $\mathrm{R} / \mathrm{B}$ to growth of sweet potato plantlets in vitro and energy consumptions of lighting. Acta Hort. 907:403-407. 